\title{
UPPER ESOPHAGEAL SPHINCTER RESTING PRESSURE VARIES DURING ESOPHAGEAL MANOMETRY
}

\author{
A pressão do esfíncter esofagiano superior varia durante a manometria esofágica \\ Daniel Tavares REZENDE ${ }^{1}$, Fernando A. M. HERBELLA ${ }^{1}$, Luciana C. SILVA ${ }^{1}$, \\ Sebastião PANOCCHIA-NETO ${ }^{1}$, Marco G. PATTI $^{2}$
}

From the ${ }^{1}$ Departamento de Cirurgia, Escola Paulista de Medicina, Universidade Federal de São Paulo, São Paulo, SP, Brasil and ${ }^{2}$ Departamento de Cirurgia, Universidade de Chicago, Chicago, IL, USA ('Department of Surgery, Paulista School of Medicine, Federal University of São Paulo, São Paulo, SP, Brazil and 2Department of Surgery, University of Chicago, Chicago, IL, USA

HEADINGS - Esophageal sphincter, upper. Manometry. Pressure.

\section{Correspondence:}

Fernando A. M. Herbella

herbella.dcir@epm.br

Financial source: none

Conflicts of interest: none

Received for publication: 14/01/2014

Accepted for publication: 22/04/2014

DESCRTORES - Esfíncter esofágico superior. Manometria. Pressão.
ABSTRACT - Background: The upper esophageal sphincter is composed of striated muscle. The stress of intubation and the need to inhibit dry swallows during an esophageal manometry test may lead to variations in basal pressure of this sphincter. Upper esophageal sphincter is usually only studied at the final part of the test. Was observed during the performance of high resolution manometry that sphincter pressure may vary significantly over the course of the test. Aim: To evaluate the variation of the resting pressure of the upper esophageal sphincter during high resolution manometry. Methods: Was evaluated the variation of the basal pressure of the upper esophageal sphincter during high resolution manometry. Were reviewed the high resolution manometry tests of 36 healthy volunteers (mean age 31 years, 55\% females). The basal pressure of the upper esophageal sphincter was measured at the beginning and at the end of a standard test. Results: The mean time of the test was eight minutes. The basal pressure of the upper esophageal sphincter was $100 \mathrm{mmHg}$ at the beginning of the test and $70 \mathrm{mmHg}$ at the end $(p<0.001)$. At the beginning, one patient had hypotonic upper esophageal sphincter and 14 hypertonic. At the end of the test, one patient had hypotonic upper esophageal sphincter (same patient as the beginning) and seven hypertonic upper esophageal sphincter. Conclusion: A significant variation of the basal pressure of the upper esophageal sphincter was observed in the course of high resolution manometry. Probably, the value obtained at the end of the test may be more clinically relevant.

RESUMO - Racional: O esfíncter esofagiano superior é constituído de musculatura estriada. O estresse da intubação e a necessidade de coibir as deglutições secas durante a manometria esofágica podem alterar a pressão basal do esfíncter esofagiano superior que geralmente é estudado somente ao final da manometria convencional. Notou-se na manometria de alta resolução significante variação no decorrer do exame. Objetivo: Avaliar a variação da pressão basal do esfíncter esofagiano superior durante a manometria de alta resolução. Método: Foi avaliada a variação de pressão basal do esfíncter esofagiano superior durante manometria de alta resolução. Foram estudados 36 voluntários sadios (idade média de 31 anos, 55\% de mulheres). A pressão basal foi aferida no início e ao término do exame. Resultados: $O$ tempo médio dos exames foi de oito minutos. A pressão basal do esfíncter esofagiano superior foi de $100 \mathrm{mmHg}$ no início do exame e de $70 \mathrm{mmHg}$ ao final, em média $(p<0.001)$. No início do teste, um paciente tinha o esfíncter esofagiano superior hipotônico e 14 hipertônicos. No final, um paciente tinha o esfíncter esofagiano superior hipotônico (o mesmo do início) e sete hipertônicos. Conclusão: Há significante variação na pressão basal do esfíncter esofagiano superior no curso manometria de alta resolução. Provavelmente, o valor obtido ao final do exame possa ser mais clinicamente relevante.

INTRODUCTION

$\mathrm{T}$ he upper esophageal sphincter (UES) is composed of striated muscle ${ }^{11}$. The stress of intubation and the need to inhibit dry swallows during an esophageal manometry test may lead to variations in its basal pressure. Conventional manometry may be inadequate for the study of the UES due to artifacts of movement and the low frequency response of water perfused systems ${ }^{1}$. Moreover, the UES is usually studied only at the end of the manometry test. During the performance of high resolution manometry (HRM) was observed that the UES pressure may vary significantly over the course of the test.

This study aimed to evaluate the variation of the resting pressure of the UES during HRM to determine the most appropriate moment to measure this pressure.

METHODS

The study was approved by the Institutional Review Board. Informed consent was signed by all individuals. There are no conflicts of interest. The authors are responsible for the manuscript, no professional or ghost writers were hired.

Were studied 36 healthy volunteers (mean age $31 \pm 10$ [18-63] years, 55\% females). Individuals with previous esophageal operations, digestive symptoms more than once a month or refusal to participate were excluded.

Esophageal manometry

All patients underwent HRM (Given Imaging, Los Angeles, USA) after fasting for eight hours. Medications that could interfere with esophageal motility were discontinued at least 
72 hours prior to the test. Acquisition and data analysis were obtained via the dedicated commercial software (ManoScan and Manoview, Given Imaging, Los Angeles, USA). The manometric protocol included an initial period of adaptation to allow individuals adjust to the presence of the trans-nasal catheter, followed by a 30-second period for landmark recording and 10 wet swallows ( $5 \mathrm{ml}$ of water) spaced by a 30 -second interval ${ }^{8}$. The manometric parameters evaluated were: a) UES resting pressure (normal value $34-104 \mathrm{mmHg}^{5}$ ) at the beginning of the test, and b) UES resting pressure at the last swallow.

\section{Statistics}

Student $t$ test was used to compare pressures. The value of $p<0.05$ was considered significant. The variables are expressed as mean \pm standard deviation [range]

\section{RESULTS}

The mean time of the test was $8 \pm 0.2$ [6-16] minutes. The resting pressure of the UES was $100.6 \pm 45.6$ [22.0-201.1] $\mathrm{mmHg}$ at the beginning of the test and 70.7 \pm 31.2 [23-147.3] $\mathrm{mmHg}$ at the end $(p<0.001)$ (Figure 1$)$.

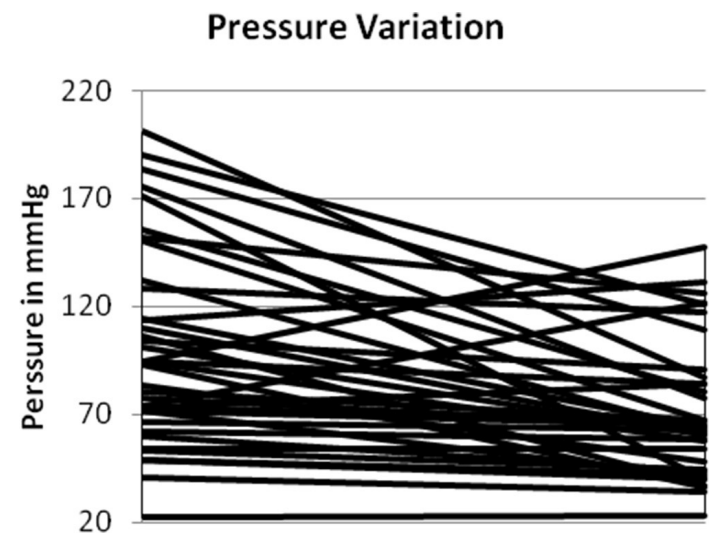

FIGURE 1 - Upper esophageal sphincter pressure variation at the beginning and at the end of the esophageal manometry

At the beginning of the test, one (3\%) individual had hypotonic UES and 14 (39\%) hypertonic. At the end of the test, one (3\%) had hypotonic UES (same patient as the beginning) and seven (19\%) hypertonic (five of them initially with a hypertonic UES).

\section{DISCUSSION}

These results show that a significant variation of the resting pressure of the UES occurs during the performance of HRM.

Conventional manometry may be an inadequate technology for the study of the UES. First, it is based on a water perfused system with a response rate to the pressure variations around $300-400 \mathrm{mmHg} / \mathrm{s}$, insufficient to properly analyze striated muscle contraction ${ }^{1}$ and leading to a constant dripping of water that stimulates the UES². Second, the elevation of the hypolaryngeal complex during swallowing causes motion artifacts $^{5}$. Last, the UES has a radial and longitudinal asymmetry ${ }^{2}$ and only four radial sensors may be inappropriate.

These disadvantages of the system lead some authors in the past to not recommend the routine study of the UES, since abnormalities were frequently found, but changes in therapy were rarely related to manometric findings ${ }^{6}$. On the other hand, HRM provides an embracing presentation of the pressure of the pharynx and esophagus by increasing the number of sensors and reducing the distance between them, eliminating the disadvantages of the conventional equipment. In addition, a solid state catheter is used, therefore avoiding the continuous dripping of water in the pharynx. A renewed interest for the UES brought to the literature a few studies published in the last years. However, there are still some aspects of the UES function that need further clarification.

Normal values for UES basal pressure has a noteworthy variance among different series but also within the same group of volunteers. Thus, extreme values as 19 and 165 may be considered normal $^{3}$. Other groups showed a normal range varying from 35 to $113^{9,10}$. The wide variation in results can be partly explained by the influence of factors affecting the measurement of the pressure of UES such as the head position ${ }^{7}$ or age of the patients ${ }^{4}$. These results also showed a significant variation of the basal pressure of the UES in the course of HRM. The stress of intubation and the need to inhibit dry swallows during an esophageal manometry test may lead to partial voluntary increase in the basal pressure of the UES at the beginning of the test. Moreover, the striated muscle is susceptible to fatigue.

\section{CONCLUSION}

Even though the current study has small number of individuals as its main limitation, all subjects evaluated were healthy volunteers and it was able to show a significant variation of the basal pressure of the UES, observed in the course of HRM. Probably, the value obtained at the end of the test may reflect a more clinically important value.

\section{ACKNOWLEDGEMENTS}

The authors are indebted to Ms. Vanessa Horich Tuxen for her invaluable help with the tests.

\section{REFERENCES}

1. Ayazi S, Crookes PF. High-resolution esophageal manometry: using technical advances for clinical advantages. J Gastrointest Surg. 2010 Feb; 14 Suppl 1: S24-32.

2. Bhatia SJ, Shah C. How to perform and interpret upper esophageal sphincter manometry. J Neurogastroenterol Motil. 2013 Jan;19(1):99-103. doi: 10.5056/jnm.2013.19.1.99.

3. Bogte A, Bredenoord AJ, Oors J, Siersema PD, Smout AJ. Normal values for esophageal high-resolution manometry. Neurogastroenterol Motil. 2013 Sep;25(9):762-e579.

4. Fulp SR, Dalton CB, Castell JA, Castell DO. Aging-related alterations in human upper esophageal sphincter function. Am J Gastroenterol. 1990 Dec;85(12):1569-72.

5. Ghosh SK, Pandolfino JE, Zhang Q, Jarosz A, Kahrilas PJ. Deglutitive upper esophageal sphincter relaxation: a study of 75 volunteer subjects using solid-state high-resolution manometry. Am J Physiol Gastrointest Liver Physiol. 2006 Sep;291(3):G525-31.

6. Malhi-Chowla N, Achem SR, Stark ME, DeVault KR. Manometry of the upper esophageal sphincter and pharynx is not useful in unselected patients referred for esophageal testing. Am J Gastroenterol. 2000 Jun;95(6):1417-21.

7. McCulloch TM, Hoffman MR, Ciucci MR. High-resolution manometry of pharyngeal swallow pressure events associated with head turn and chin tuck. Ann Otol Rhinol Laryngol. 2010 Jun;119(6):369-76.

8. Roman S, Kahrilas PJ, Boris L, Bidari K, Luger D, Pandolfino JE. Highresolution manometry studies are frequently imperfect but usually still interpretable. Clin Gastroenterol Hepatol. 2011 Dec;9(12):1050-5.

9. Salvador R, Dubecz A, Polomsky M, Gellerson O, Jones CE, Raymond DP, Watson TJ, Peters JH. A new era in esophageal diagnostics: the image-based paradigm of high-resolution manometry. J Am Coll Surg. 2009 Jun;208(6):1035-44.

10. Silva LC, Herbella FA, Neves LR, Vicentine FP, Neto SP, Patti MG. Anatomophysiology of the Pharyngo-Upper Esophageal Area in Light of High-Resolution Manometry. J Gastrointest Surg. 2013 Sep 28.

11. Sivarao DV, Goyal RK. Functional anatomy and physiology of the upper esophageal sphincter. Am J Med. 2000 Mar 6;108 Suppl $4 a: 27 S-37 S$ 